Brandeis | цввая

brandeis.edu/j-caste
CASTE: A Global Journal on Social Exclusion

Vol. 2 No. 2 pp. $235-264$

October-November 2021

ISSN 2639-4928

https://doi.org/10.26812/caste.v2i2.339

\title{
Norm Entrepreneurship at the UN-Dalits and Communities Discriminated on Work and Descent
}

\author{
Paul Divakar Namala'
}

\begin{abstract}
Human rights are rights inherent to all human beings. However, caste-based discrimination is one of the areas that most human rights mechanisms overlook. As a result of several interventions by Dalit and human rights organisations, the erstwhile United Nations body, in 2000, has termed it 'discrimination based on work and descent'. The above Dalit and other International organisations have also brought evidence before the UN Committee on the Elimination of Racial Discrimination which has endorsed caste-based discrimination as part of the discrimination based on descent, in Article I of the International Convention on the Elimination of All Forms of Racial Discrimination (CERD). Further, it was also brought to the notice of various Special Rapporteurs and UN Committees that communities discriminated on work and descent (CDWD) face severe human rights violations and abuses that continue to restrain the socio-economic development of these specific groups of people in several countries globally. Dalit organizations and their solidarity bodies have gone ahead through a process of 'norm entrepreneurship' at the UN levels. This article narrates and analyses the challenges and human rights consequences of caste and discrimination based on work and discusses the norm entrepreneurship journey of Dalits and CDWD at the UN level.
\end{abstract}

\section{Keywords}

Norm entrepreneurship, Caste-based discrimination, Dalits, communities discriminated on work and descent, modern slavery, treaty body, exclusion, intergenerational discrimination, CERD

\footnotetext{
'Convenor, Global Forum of Communities Discriminated on Work and Descent (GFoD), The Inclusivity Project (TIP), New York

E-mail: pauldivakar@theinclusivityproject.org
}

(C) 202I Paul Divakar Namala.This is an open access article distributed under the terms of the Creative Commons Attribution License, which permits unrestricted use, distribution, and reproduction in any medium, provided the original author(s) and source are credited. 
Discrimination based on work and descent is any distinction, exclusion, restriction, or preference based on inherited status such as caste, including present or ancestral occupation, family, community or social origin, name, birthplace, place of residence, dialect and accent that has the purpose or effect of nullifying or impairing the recognition, enjoyment, or exercise, on an equal footing, of human rights and fundamental freedoms in the political, economic, social, cultural, or any other field of public life. This type of discrimination is typically associated with the notion of purity and pollution and practices of untouchability and is deeply rooted in societies and cultures where this discrimination is practiced. ${ }^{1}$ — Prof. Chin-Sung Chung

\section{Human Rights are Rights Inherent to all but ...}

United Nations several organs are the single most collective institutions for protecting and promoting human rights across the globe. The UN asserts that human rights are rights inherent to all human beings, regardless of race, sex, nationality, ethnicity, language, religion, or any other status. Human rights include the right to life and liberty, freedom from slavery and torture, freedom of opinion and expression, the right to work and education, and many more. However, of a particular category of status, which has not sufficiently been stressed on or has not been mentioned or deemed to have been covered under one of the lists mentioned above, there is the possibility that the particular issue or community get excluded from being covered under the umbrella of guaranteed rights.

Awareness of caste-based discrimination and that of other communities and discrimination based on Work and Descent (DWD) has been as old as the UN itself. While framing the Universal Declaration of Human Rights (UDHR) in 1946, one of the considerations expressed by W.E.B. Du Bois, ${ }^{2}$ who was a proponent of the rights of Afro-descendants, was how to include the concerns of the so-called 'untouchable' communities of South Asia. This was also attempted again while evolving the International Convention for the Elimination of Racial Discrimination (CEDR) in 1965, when it was presumed that the concerns of the so-called 'untouchables' would be handled with that instrument.

After all these decades, it has been proved that it is an arduous task to include caste-based discrimination as one of the areas for human rights mechanisms to address. Why? There may be three reasons for this gap. The decision to have an issue or name a particular community, under a convention or a resolution rests on the member states at the UN. It is evident that there is a solid resistance to interrogate this issue of caste-based discrimination and genuinely seek its remedies by the member states. Second, unlike many others, this is not a north-south issue between member states. In all the countries, caste-based discrimination exists; it is an issue within the

${ }^{1}$ Human Rights Council. Eleventh Session 2-19 June 2009, Agenda item 5. Human Rights Bodies and Mechanisms. Final report of Mr. Yozo Yokota and Ms. Chin-Sung Chung, Special Rapporteurs on the topic of discrimination based on work and descent. 1A/HRC/11/CRP.3, 18 May 2009. Retrieved from https://www. ohchr.org/Documents/HRBodies/HRCouncil/ RegularSession/Session11/A-HRC-11-CRP3.pdf

${ }^{2}$ W.E.B. Du Bois Papers. Series 1. Correspondence Letter from B. R. Ambedkar to W.E.B. Du Bois. Retrieved from https://credo.library.umass.edu/view/full/mums312-b109-i132 
borders of the member states. No country is ready to 'wash its dirty linen' publicly. Therefore, there is a great deal of resistance, and even an active effort, to block any resolution or attempt to address this issue. Several technical reasons are given to assert that the respective instrument or mandate does not cover the particular issues of castebased discrimination. Third, there is an illusion that it is an internal matter and refers to a culture of the land and particular to one specific sub-region and therefore does not warrant UN's intervention. Despite these barriers in accessing UN mechanisms, Dalit and Human Rights organisations have pursued the realization of a "norm architecture' as the issues facing DWD Communities are severe and have been for too long unaddressed, and if addressed in some countries, the implementation is relatively weak. It was recognized in the early years itself that there are major gaps in UN norms in addressing caste and DWD concerns.

\section{Issues facing CDWD}

CDWD, numbering more than 260 million people worldwide, are among the most marginalised and excluded peoples, many of whom are living in conditions of slavery often tied to descent. They transcend religious, geographical and ethnic boundaries and are a global phenomenon. Previously described as communities who are affected by 'caste and analogous systems' of social stratification and 'discrimination based on work and descent', ${ }^{3}$ they are commonly known as Dalits, Roma-Sinti, Quilombola, Burakumin, Haratine, Oru, Shambara, amongst many other names and fall under the umbrella term 'Communities Discriminated on Work and Descent' (CDWD). The following are some of the specific types of human rights issues faced by CDWD.

Intergenerational discrimination and violation of fundamental human rights: CDWD faces intergenerational discrimination, ${ }^{4}$ exclusion from public resources and entitlements, and are routinely segregated ${ }^{5}$ despite constitutional and legal protective measures in many countries. In most countries, they are subjected to contemporary and even traditional forms of slavery. ${ }^{6}$ In Asia, they face a particular form of exclusion and violence commonly known as 'untouchability'. 7 Any attempt

${ }^{3}$ United Nations General Assembly. Human Rights Council. Thirty-first session. Agenda item 3. Report of the Special Rapporteur on minority issues. A/HRC/31/56, 28 January 2016. Retrieved from https://www.ohchr.org/ EN/HRBodies/HRC/RegularSessions/Session31/Documents/A HRC_31_56_en.doc

${ }^{4}$ United Nations General Assembly. Human Rights Council. Thirty-fourth session. Agenda item 3. Report of the Special Rapporteur on minority issues o her mission to Iraq. A/HRC/34/5, 9 January 2017. Retrieved from https://documents-dds-ny.un.org/doc/UNDOC/GEN/G17/002/44/ PDF/G1700244.pdf?OpenElement

${ }^{5}$ United Nations General Assembly. Human Rights Council. Twenty-third session. Agenda item 9. Report of the Special Rapporteur on contemporary forms of racism, racial discrimination, xenophobia and related intolerance, Mutuma Ruteere. A/HRC/23/56, 2 April 2013. Retrieved from http://idsn.org/wp-content/uploads/user_folder/ pdf/New_files/UN/SP/HRC23_report_ SR_Racism.pdf

${ }^{6} \mathrm{UN}$ Committee on the Elimination of Racial Discrimination (CERD). UN Committee on the Elimination of Racial Discrimination: Concluding Observations. Mauritania, 10 December 2004, CERD/C/65/CO/5. Retrieved from https://www.refworld.org/docid/42d2676f4.html ${ }^{7} \mathrm{UN}$ Committee on the Elimination of Racial Discrimination. Concluding observations on the combined $17^{\text {th }}$ to $23^{\text {rd }}$ periodic reports of Nepal: Committee on the Elimination of Racial 
to challenge discriminatory practices is countered with severe and extreme forms of violence. Women and children among these communities bear additional layers of discrimination and violence.

Violence against women: Girls and women among the CDWD face extreme forms of violence by wider society, are paid unequal wages, and are underpaid. ${ }^{8}$ There is a greater, significant proportion of unpaid work among these women. Often women of CDWD face extreme violence, sexual assault, rape and even murder and mutilation as form of vengeance against the whole community.

Children of CDWD: They face extreme forms of violence and discrimination at schools and in society in several countries. Practices of forced child labourers ${ }^{9}$ and trafficking are prevalent among them.

Poverty and hunger: CDWD are disproportionately affected by hunger, ${ }^{10}$ food insecurity and poverty, primarily as a result of systemic and systematic discrimination and the arbitrary nature of daily wage labourers regarded as 'inferior', their lack of social, economic and political power and reliance on volatile agricultural harvest due to climate change and other factors. Insufficient data is available to paint a conclusive picture of malnutrition or undernourishment rates of CDWD. Special measures need to be undertaken to ensure that the country and community-specific interventions are provided the most immediate needs of the most vulnerable regarding rights to food.

Exclusion and Discrimination in Education: CDWD face discrimination at all levels of education, from primary to higher to technical and professional education in most countries. Cultural practices and beliefs deny millions the right to receive quality education. Notions of 'impurity', ${ }^{11}$ child slavery, trafficking, and poverty are factors that prevent children, youth and adults of CDWD from receiving and accessing quality education.

Denial of Access to water and sanitation: 2.2 billion people worldwide do not have secure access to safe drinking water. This has devastating consequences for the health of the affected persons and leads to poorer education prospects and is a threat to female empowerment since the burden of collecting water often falls on women and girls. To be noted here is that during the COVID-19 pandemic, access to water, hygiene products and sanitation facilities were severely restricted for CDWD. CDWD

Discrimination. 29 May 2018. CERD/C/NPL/CO/17-23. Retrieved from file://C:/Users/ Admin/Downloads/CERD_C_NPL_CO_17-23-EN.pdf

${ }^{8}$ Eduardo Araújo and Givânia Maria da Silva. Racism and Violence against Quilombalos in Brasil. Confluencias. Vol.21. No.2. 2019, pp.196-208.

${ }^{9}$ United Nations. International Covenant on Civil and Political Rights. Human Rights Committee. Concluding observations on the second periodic report of Nepal. 15 April 2014. CCPR/C/NPL/ $\mathrm{CO} / 2$. Retrieved from https://tbinternet.ohchr.org/_layouts/15/treatybodyexternal/Download. aspx?symbolno $=\mathrm{CCPR} / \mathrm{C} / \mathrm{NPL} / \mathrm{CO} / 2 \&$ Lang $=$ En.

${ }^{10}$ United Nations. International Convention on the Elimination of all Forms of Racial Discrimination. Committee on the Elimination of Racial Discrimination. Seventieth session. Consideration of Reports Submitted by States Parties Under Article 9 of the Convention: Concluding Observations of the Committee on the Elimination of Racial Discrimination-India. 5 May 2007, CERD/C/IND/CO/19. Retrieved from https://binternet.ohchr.org / layouts/15/ treatybodyexternal/Download.aspx?symbolno=CERD/C/IND/CO/19\&Lang=En.

${ }^{11}$ United Nations General Assembly. Human Rights Council. Seventeenth session. Agenda item 9. Report of the Special Rapporteur on contemporary forms of racism, racial discrimination, xenophobia and related intolerance, Githu Muigai. 25 March 2011, A/HRC/17/40/Add.2. Retrieved from https://digitallibrary.un.org/record/700115? ln=en 
face additional challenges even during normal times due to exclusive social practices. During the COVID-19 pandemic, cases in Asia and Europe emerged in which access to public water and sanitation facilities were either restricted or denied. This situation escalated in South Asia during the summer months when infections peaked; Dalits were prohibited from accessing public water/sanitation facilities for being considered 'unclean'. Despite such rampant discriminatory practices, governments fail to ensure access to these facilities across the globe for CDWD.

Access to housing and adequate shelter: During the COVID-19 pandemic, the lack of adequate housing and shelter became evident when, during lockdowns and curfews, millions either did not have a home to go to or the virus was able to rapidly spread in inadequate and cramped conditions of housing. This problem is particularly pertinent for CDWD who are denied housing facilities and experience discrimination in housing conditions. Alongside segregation in housing, other related problems need to be addressed to guarantee all persons, their economic, social and cultural rights to adequate housing and shelter.

Access to land and livelihoods: To achieve decent work conditions and alleviate some of the negative effects of the pandemic, land tenure and ownership have been claimed as a vital condition for CDWD. In Brazil, the Sahel and the large parts of South Asia, land rights and land tenure and ownership remain a central demand for many CDWD and represents a multitude of possible consequences such as food security and economic opportunity, reduction of poverty and homelessness, etc.

Frontline healthcare workers and sanitation workers: Conversely, frontline health care workers, sanitation workers, street cleaning workers, workers in the mortuaries and burial or crematoriums in several countries such as India, Pakistan and Nepal are almost exclusively from CDWD. They are being denied both personal protective equipment like masks or gloves, and they are excluded from the healthcare system by not having healthcare insurance or other support mechanisms.

Contemporary forms of slavery for millions: Poor implementation of the existing legal framework at the national and international levels and the state's apathy to tackle the issues of modern forms of slavery are of serious concern to CDWD. According to the latest available comprehensive data, 40.3 million people globally are facing the problem. ${ }^{12}$ With CDWD, factors like intergenerational discrimination, the perpetuation of social hierarchies, and restrictions to social mobility make these communities susceptible to contemporary forms of slavery. In addition, key features of modern forms of slavery are closely associated with the concept of CDWD, including debt bondage, forced labourers, child labourers, unpaid and underpaid work, trafficking and forced marriages. However, while discussing contemporary forms of slavery, CDWD is often ignored or invisible in the discussion, and the link between the established discriminations faced by these communities and contemporary forms of slavery is grossly overlooked.

Climate change: Climate change is the most significant and severe contemporary global threat to the planet, which a decisive global action must stop. But what is worse is that climate change perpetuates inequalities and severely affects the most vulnerable,

${ }^{12}$ Global Slavery Index 2018. Retrieved from https://www.globalslaveryindex.org/ 
particularly those whose livelihoods depend on natural resources. Many CDWD are highly dependent on earnings from agricultural labourers and livestock, forests and other lands. ${ }^{13}$ With fewer to no resources and options to combat, mitigate or adapt, the internalization of discrimination and exclusion continue to deepen their state of deprivation and marginalisation. Their locational, social and economic vulnerabilities place a greater strain on their adaptive capacity to climate change and ability to deal with shocks, stresses and change.

Discrimination in disaster relief and rehabilitation and in Disaster Risk Reduction Practices: CDWD face discrimination in several disaster risk reduction (DRR) practices. This has been evidenced in several countries during several DRR practices, including pre-disaster warnings, habitations located in vulnerable geographical areas, exclusion from rescue and relief measures, not being counted in rehabilitation entitlements and facing exclusion in rehabilitation measures. Therefore, clear measures need to be framed to ensure inclusive measures and practices.

Access to relief and health care during COVID-19 pandemic: Several instances of discrimination were evident when accessing health care and other assistance during the pandemic. In fact, the existing discriminatory practices surfaced in their most blatant forms during the pandemic, impeding healthcare and state relief programs.

Discrimination in access to public finance and development: CDWD, especially women, children, people with disabilities and sexual minorities among them face exclusion in access to civic amenities including education, health care and other entitlements. Within countries it is also observed that there is an inherent bias in the management of public finance management and in access to development.

This is indeed a grim picture of CDWD across the regions. In some areas, the communities face extreme poverty and are subjected to severe human rights violations. The narratives from ground-level activists are even grimmer. This is evidenced by compilations from the UN thematic bodies and special procedures mandate holders apart from the data generated from CSOs and human rights organisations working in respective countries. Over the last two decades, from the year 2000 onwards, several organisations and individuals have made focussed and informed interventions to the UN bodies through collated data and evidence on the issues of DWD in the wider societies, particularly among the Asian, African and European and the Latin American regions. These efforts have strengthened the network among CDWD and through these networks, they have made interventions into both the Geneva-based UN bodies and New York-based organizations.

\section{The Norm Entrepreneurship Journey of Dalits and CDWD at the UN}

The Dalit communities having experienced generation of the above forms of 'untouchability' resulting in discrimination, exclusion and violence, have persisted to address effectively through a process of norm entrepreneurship ${ }^{14}$ at national and UN levels. This was initiated with the coming together of diverse groups of Dalits

${ }^{13}$ Amita Bhaduri. Impact of Climate Change on Life \& Livelihood of Dalits: An Exploratory Study from Disaster Risk Reduction Lens. New Delhi: NCDHR and SPWD. 2013. p. 3.

${ }^{14}$ The process of non-state actors creating new norms has been termed 'norm entrepreneurship' in International Relations (IR) scholarship. Florini (1996), p.375; Finnemore and Sikkink 
and those in solidarity from several sections of society, initially in India, as National Campaign on Dalit Human Rights (NCDHR) in 1998, and then building up an international solidarity movement across northern countries, that is, the International Dalit Solidarity Network (IDSN) in 2000. Asia Dalit Rights Forum (ADRF) was then initiated in 2009 to link the CDWD communities in Asia. In early 2019, Africa Network of communities discriminated on work and descent against slavery (ANDS) was initiated with organisations working in Senegal, Mauritania, Mali, Niger, Burkina Faso Mauritius, Somalia and some pan-African networks. The International Congress of Communities Discriminated on Work and Descent (ICDWD) held in New York in September 2019 consisted of 121 representatives from twenty-four countries. They gathered to forge the Global Forum of Communities Discriminated on Work and Descent (GFoD).

Over two decades, this journey moved towards building policy norms concerning human rights of the CDWD, initially with a Dalit focus and later collectively with such communities as Roma, Burakumin, and Haratine Quilombola, etc. This journey may be seen in four phases since the emergence of the International Covenant for Elimination of Racial Discrimination (CERD): 1) Pre-World Conference Against Racism (WCAR), 2) WCAR and its Prep, 3) CERD and HRC, and 4) UN GA and ECOSOC phase.

\section{Pre-World Conference Against Racism Phase}

The first phase, Pre-WCAR Phase, from 1996 till 1999: In 1996, CERD recognized human rights abuse and discrimination faced by Scheduled Castes and Tribes ${ }^{15}$ referring to the continued discrimination and violence they face despite constitutional mechanisms. The International Covenant on Civil and Political Rights (ICCPR) first noted severe shortcomings in the performance of the Government of India and noted in the concluding remarks to the reports submitted in 1997 that 'despite measures taken by the Government, members of scheduled castes and scheduled tribes, as well as the so called backward classes and ethnic and national minorities continue to endure severe social discrimination and to suffer disproportionately from many violations of their rights under the Covenant, inter alia inter-caste violence, bonded labourers and discrimination of all kinds'. ${ }^{16}$ In 2000, the Convention on the Elimination of All Forms of Discrimination against Women (CEDAW) raised numerous questions on the plight of Dalit women in response to India's country report. There were only tentative and intermittent interventions made mainly to the CERD, Human Rights Committee (HRC) and CEDAW and the Special Rapporteur on Contemporary Forms of Racism, Racial

(1998), p. 889 cited in Corrine Lennox. Transnational Social Mobilisation and Minority Rights: Identity, Advocacy and Norms. London: Routledge, 2020.

${ }^{15} \mathrm{UN}$ Committee on the Elimination of Racial Discrimination (CERD). UN Committee on the Elimination of Racial Discrimination: Concluding Observations, India, 17 September 1996, CERD/C/304/Add.13. Retrieved from https://www.refworld.org/docid/3ae6aeeb10.html ${ }^{16} \mathrm{UN}$ Human Rights Committee (HRC), UN Human Rights Committee: Concluding Observations of the Human Rights Committee, Slovakia. 4 August 1997, CCPR/C/79/Add.79. Retrieved from https://www.refworld.org/ docid/3ae6b032c.html 
Discrimination, Xenophobia and Related Intolerance. However, they did not raise much of a debate nor a serious step to take necessary action against discrimination and violence. These remarks were mainly due to the interventions of some international human rights organisations, and the participation of Dalit rights organisations was very limited; the latter's focus was mostly on the domestic measures, and that, too, mostly sub-national.

\section{WCAR, Durban and its Preparatory Phase}

The second phase was of WCAR and its Preparatory Phase. In this phase the most notable process has been the emergence of Dalit organisations both at a sub-national and national level in India. In this period, Dalit CSOs had mobilised a host of human rights organisations - Dalit and other international human rights organisations - to demand inclusion of caste-based discrimination in the list of causes for human rights violations. This is the beginning of 'norm entrepreneurship' taken up by the Dalit movements and CSOs working for the cause of human rights and Dalit rights. This was done through several diverse spaces that were identified by the Dalit CSOs, and systematic interventions were made towards upholding the cause of Dalit rights.

As a preparation for the World Conference, six Regional Experts' Seminars were held between 1999 and 2000 in Geneva, Warsaw, Bangkok, Addis Ababa, and Santiago de Chile. The objectives of each seminar were to discuss the issues of priority concern for that particular region, advance the regional dialogue on racism, raise awareness, share information on the issues of racism and intolerance, and share the 'best practices' to serve as agenda for the future.

The African Regional Seminar of Experts on the prevention of 'ethnic and racial conflicts in Africa' in Addis Ababa, October 2000, called for 'in-depth study of the question of castes, in particular in Africa'. ${ }^{17}$ In the Asia Pacific Preparatory Meeting held in Tehran, April 2001, again the issue of caste-based discrimination (CBD) was raised by the Dalit representatives of the CSOs. The admission of the Government of Nepal of the problem of caste discrimination against Dalits in their country and their willingness to have the issue squarely addressed in the WCAR was very encouraging to those who were raising the issue of caste discrimination. ${ }^{18}$

The United Nations Commission on Human Rights, acting as the Preparatory Committee for WCAR commissioned the International Human Rights Law Group led by Dr. Gay McDougal to prepare a draft agenda for the WCAR conference. This was held in January 2000 in Bellagio, Italy. N. Paul Divakar of National Campaign on Dalit Human Rights (NCDHR) $)^{19}$ was among the invitees who participated in the Bellagio Consultation and raised the issue of CBD and the criticality of WCAR addressing this crucial issue faced by a vast section of the global population.

\footnotetext{
${ }^{17}$ Joint statement submitted by the Federation Internationale des Ligues des Droits de l'Homme and the Lutheran World Federation to the Sub Commission on the Promotion and Protection of Human Rights, $17^{\text {th }}$ August 2001.

${ }^{18}$ N. Paul Divakar and Ajai M., UN Bodies and the Dalits. In Sukhdeo Thorat and Umakant. (Eds.) Caste, Race, and Discrimination: Discourses in International Context. New Delhi: Rawat Publications, 2004.

${ }^{19}$ Corinne Lennox. Transnational Social Mobilisation and Minority Rights - Identity, Advocacy and Norms. London: Routledge, 2020.
} 
Two preparatory intergovernmental meetings were planned to bring further the concerns raised by the Regional Experts Seminars and discuss and finalise the agenda drafted by the Bellagio Consultation. The first was held in Geneva from 1 to 5 May 2000, and the second was also held in Geneva from 21 May to 1 June 2001. In both these 'Prep Coms' (preparatory committee meetings) the Dalit representatives were exceptionally well prepared and their participation was intense and focussed. In fact, at all the consultations, there were Dalit representatives and other human rights organisations who were well equipped with evidence-based data and clarity of purpose to make a strong appeal that WCAR must address CBD.

It was during this WCAR preparatory phase from the year 2000 onwards that the caste-based discrimination became globally visible and became a hotly contested subject for two parties as well as a matter of concern for UN agencies - CSOs on the one side, voicing ground-level concerns of increasing and persisting discrimination and violence against CDWD, and the member states on the other, shielding themselves from the international gaze against this heinous crime whereas Office of the United Nations High Commissioner for Human Rights (OHCHR) and members of several monitoring bodies like CERD supporting the stand of the CSOs and demanding inclusion of this issue of caste-based discrimination in the WCAR documents and the UN mechanisms.

Solidarity and support also came in from another major platform. The NGO Conference at WCAR, Durban, strongly demanded the inclusion of 'work and descent' based discrimination in the discourse and document of WCAR ${ }^{20}$ The NGOs at the Conference came together to identify the continuing forms of exclusion, discrimination and violence faced by communities in different parts of the world. Many representatives from Asia and Africa identified the issue of caste and analogous types of discrimination based on one's birth as forms of 'hidden apartheid' requiring attention and addressal of the world community. A strong contingent of over 200 delegates of Dalits from across South Asia, the Buraku people of Japan, the Osu and Oru people of Nigeria, the Griots of Senegal and other communities voiced that similar forms of discrimination exist and have not been recognized under any UN treaty. Specifically pointing out the context of women and children of these communities who were distinctly vulnerable to brutal forms of violence, the NGO Conference recognized the role and task of individual states and the UN as a body to eradicate work and descentbased discrimination, including caste discrimination and untouchability.

On the opening day of the WCAR on 31 January 2001, at the Round Table of Heads of Member States, the NCDHR was one of the three organisations invited to present their issue. Paul Divakar presenting the issue appealed to the Heads of States to make necessary provisions to address the concerns of the 260 million people who are victims of caste discrimination in South Asia and Western Africa. Fidel Castro, the then President of Cuba, expressed shock that such a system is still being practiced but no resolution has come out from the Roundtable on the issues of caste discrimination.

At the 'Voices of Victims' programme organized as part of the official programme of the UN World Conference Against Racism, in 2001, Manimalai, from Tamil Nadu, India, wife of slain panchayat (village council) president Murugesan, presented her case. Murugesan was dragged out of the public transport, beheaded and murdered in

${ }^{20} \mathrm{Ibid}$. 
broad daylight as he had dared to contest in the panchayat elections against the diktat of the dominant caste community. The irony was that the panchayat seat was reserved for Dalits and Murugesan enjoyed the right to contest!

On 5 September 2001, the National Human Rights Commission (NHRC), an independent body monitoring human rights violations in India and represented by Justice K Ramaswamy, made its statement at the WCAR conference. Referring to the two preparatory consultations organized by the Commission within the country in preparation for the WCAR and in the light of the myriad cases dealt with by the Commission, Justice Ramaswamy stated that while India has formulated legislations, discrimination against scheduled castes (Dalits) continued to be the reality and that Member States, including India, must take this opportunity to address this vexatious problem while respecting the international human rights regime established under the auspices of the United Nations, and accordingly observe the discipline of the treaties to which they are States Parties. ${ }^{21}$ This was undoubtedly a big boost to the campaigning Dalit organisations.

One of the member States, Barbados, observing the interventions brought by the Dalit organisations and other International Human Rights Organisations proposed a clause which was in the Draft Declaration and Programme of Action (DDPA) and this was included as para no.73 of the DDPA. Para no.73 read as follows: 'to ensure that all necessary constitutional, legislative and administrative measures, including appropriate forms of affirmative action are in place to prohibit and redress discrimination based on work and descent, and that such measures are respected and implemented by all state authorities at all levels'.

The perseverance of the Dalit organisations continued. The NGO representatives and survivors of caste and analogous forms of discrimination met with state representatives and UN CERD members, including Mary Robinson, High Commissioner for Human Rights, to submit written representations requesting that the conference recognizes this CDWD issue as of paramount importance.

\section{Tearing down the wall of caste}

Madam Navi Pillay, UN High Commissioner for Human Rights, OHCHR, Geneva in an Opinion Piece: Tearing down the wall of caste, ${ }^{22}$ while receiving a group of representatives from caste-affected communities in Asia including Wilson Bezwada of Safai Karamchari Andolan (Movement for the Elimination of Manual Scavenging), who presented the High Commissioner with a piece of brick from the wall of a torn down dry latrine, said that the brick symbolised the global struggle against the caste and discrimination based on work and descent. Madam Pillay also recognised that 'Untouchability' is a social phenomenon affecting approximately 260 million persons worldwide. She also opined that the time has come to eradicate the shameful concept

\footnotetext{
${ }^{21}$ Justice K. Ramaswamy. 'Statement by National Human Rights Commission, India at WCAR'. In Sukhadeo Thorat and Umakant. (Eds.) Caste, Race and Discrimination. New Delhi: Rawat Publication, 2004.

${ }^{22}$ United Nations Human Rights. Opinion Piece: Tearing down the wall of caste. UN High Commissioner for Human rights, OHCHR, Geneva https://newsarchive.ohchr.org/EN/ NewsEvents/Pages/DisplayNews.aspx?News ID=9540\&LangID=E
} 
of caste. 'Other seemingly insurmountable walls, such as slavery and apartheid, have been dismantled in the past. We can and must tear down the barriers of caste too.'

Despite the intense advocacy of engaging with the State Party Delegates, raising international media visibility and generating support from a wide network of civil society organizations, Para 73 referring to 'discrimination based on work and descent' did not find place in the DDPA. This was a great disappointment for Dalit rights organisations. However, the fallout of this denial caught global attention. This also caught the attention of the OHCHR and the UN Thematic Conventions such as CERD and Committee on Economic, Social and Cultural Rights (CESCR) and other Special Rapporteurs as to why such a legitimate concern, a human rights issue concerning 260 million people could be set aside by the WCAR. This gave impetus to all concerned bodies and organizations, both civil and UN, push the CDWD issue to move towards its third phase.

\section{CERD and HRC phase}

The third phase of the norm entrepreneurship of CDWD rights is significant in carving out detailed policy framework to protect and promote the CDWD rights from several perspectives. There are five critical elements in this phase: (a) UN CERD General Recommendation $29^{23}$ on caste-based discrimination and communities discriminated by work and descent, (b) UN Sub-Commission reports of Special Rapporteurs Goonesekere's report; Asbjorn Eide and Yozo Yakota's report culminating in the document 'Principles and Guidelines for Elimination Caste and Discrimination based on Work and Descent' by Yozo Yokota and Chin-Sung Chung, (c) UN Treaty Bodies Concluding Observations with reference to caste discrimination (1991-2017), ${ }^{24}$ (d) UN Special Measures and, (e) Office of the High Commissioner on Human Rights (OHCHR) commissioned 'Guidance Tool on Descent-Based Discrimination: Key Challenges and Strategic Approaches to Combat Caste-Based and Analogous Forms of Discrimination' to be used by the UN agencies and other stakeholders in addressing caste-based discrimination, ${ }^{25}$ (f) Parliamentary Resolutions and Motions and (g) Parliamentary Forums

(a) CERD General Recommendation 29: CERD has played a critical role in the international recognition of caste and discrimination based on descent in the UN from 1996. Dalit and human rights organisations have been engaging with CERD to address caste-based discrimination as a form of discrimination in order to take note

\footnotetext{
${ }^{23}$ Committee on the Elimination of Racial Discrimination. General Recommendation 29, Discrimination Based on Descent (Sixty-first session, 2002). U.N. Doc. A/57/18 at 111 (2002), reprinted in Compilation of General Comments and General Recommendations Adopted by Human Rights Treaty Bodies, U.N. Doc. HRI $\backslash$ GEN $\backslash 1 \backslash$ Rev.6 at 223 (2003). Retrieved from http://hrlibrary.umn.edu/cerd/genrec29.html

${ }^{24}$ IDSN. 2021. Caste Discrimination and Human Rights-Compilation of UN References. Retrieved from https://idsn.org/wp-content/uploads/2021/01/UNcompilation-Jan-2021.pdf ${ }^{25}$ United Nations. 2017. Guidance Tool on Descent-Based Discrimination: Key Challenges and Strategic Approaches to Combat Caste-Based and Analogous Forms of Discrimination - United Nations Network on Racial Discrimination and Protection of Minorities. Retrieved from https:// www.ohchr.org/Documents/Issues/ Minorities/GuidanceToolDiscrimination.pdf
} 
of (i) the several reviews of the country reports of India, Nepal, Bangladesh, Burkino Faso, Japan, Micronesia, UK and many other countries and (ii) the way caste-based discrimination was avoided in WCAR. Taking note of the appeals from the Dalit organisations, CERD held a special session to address caste-based discrimination.

General Recommendation 29 of CERD reaffirms that discrimination based on descent includes discrimination against members of communities based on forms of social stratification such as caste and analogous systems of inherited status which nullify or impair their equal enjoyment of human rights; and condemns descent-based discrimination, such as discrimination on the basis of caste and analogous systems of inherited status, as a violation of the Convention. It further endorsed that all states take 'steps to identify those descent-based communities under their jurisdiction who suffer from discrimination, especially on the basis of caste and analogous systems of inherited status' (General Recommendation XXIX on article 1, paragraph 1, on the Convention (Descent) of CERD). This is the first such direct pronouncement on addressing caste-based discrimination by any of the UN Convention monitoring bodies. It spelled out a set of good practices to address discrimination based on caste and analogous systems.

CERD has been the most expressive on the subject of discrimination on work and descent including caste. It has made several concluding remarks while examining the country reports of Bangladesh (2001), Sri Lanka (2016), Japan (2001, 2010, 2014), UK 2003, 2011, 2016), Yemen (2006, 2011), Nigeria (2005), Mauritania (2004), Madagascar (2004), Senegal 2002, 2012), Chad (2009, 2013), Mali (2002), Ethiopia (2003,2009), Ghana (2003), Mauritius (1996, 2013), Burkina Faso (1997, 2013) and Suriname (2015) - a total of 16 countries and 39 citations on Caste and DWD. In addition, several other treaty body conventions have cited on DWD and Caste, which are detailed in Annexure 1 and a little more in detail in the UN treaty body section below.

(b) UN Sub-Commission and HRC: Parallelly, another stream of actions were initiated by the Dalit organisations through the erstwhile UN Sub-Commission on Protection and Promotion of Human Rights. In 2000, the Sub-Commission entrusted R.K.W. Goonesekere, its member from Sri Lanka, with the task of preparing a pioneering working paper on the subject in order to identify communities facing discrimination on work and descent, examine the existing constitutional, legislative and administrative measures for the abolition of such discrimination and to make concrete recommendations and proposals for the effective elimination of such discrimination as may be appropriate in the light of such examination.

The Sub-Commission in 2004, appointed Special Rapporteurs AsbjØrn Eide and Yoko Yakota who submitted their report on Prevention of Discrimination based on Work and Descent to the ECOSOC. In this report both Eide and Yakota categorically identified caste or DWD communities found in the globe, including Bangladesh, Burkina Faso, India, Japan, Kenya, Mali, Micronesia, Nepal, Pakistan, Senegal, Sri Lanka and Yemen. Further, they found DWD identities in various diaspora in Europe and Americas and similarly discriminated communities existing around the world. 
Principles and Guidelines for eliminating DWD - Yozo Yokota and Chin-Sung Chung: This is the first such UN instrument proposed by the two Special Rapporteurs which is a potential tool for Elimination of DWD including caste and analogous forms of discrimination. Unfortunately, in the transition process from UN Sub-Commission to UN HRC, this is one of the powerful instruments that has been left hanging in limbo as the HRC neither accepted this report nor rejected it. Efforts are still being made to have the HRC adopt these Principles and Guidelines.

(c) UN Treaty Bodies Concluding Observations with reference to Caste Discrimination (1991-2017). ${ }^{26}$ In another parallel stream, Dalit rights organizations and human rights bodies had intense and active engagement with the Treaty BodiesCERD (1965), CCPR (1966), CRC (1989), CEDAW (1979) and CESCR (1966). In this respect, the IDSN must be commended a great part of this facilitation of Dalit and CDWD voices from the ground to intervene with clear facts and figures and put forward recommendations in addressing the CDWD concerns. A total of 19 references were made by Treaty bodies concerning 10 countries in Africa-Nigeria, Mauritania, Madagascar, Senegal, Chad, Mali, Ethiopia, Ghana, Mauritius and Burkina Faso. In eight countries in Asia, Middle-East and the Pacific-Micronesia, India, Nepal, Pakistan, Bangladesh, Pakistan, Japan and Yemen-wherein 65 Observations have been made by the UN Treaty Bodies observing the need to address either DWD or specifically caste discrimination. Similarly, three observations in Europe (UK) and one observation in the Latin American Region (Suriname) have been made by the Treaty bodies. This massive piling of evidence of pervasive global nature decisively brought out the prevalence and perpetuation of discrimination based on work and descent (For details, see Table 1 in the Annexure).

Table I: Details of the Treaty Bodies Concluding Observations with reference to Caste Discrimination (199I-2017). This table details country-wise concluding observations made by Treaty bodies. The brackets after the country refer to the number of times Treaty bodies have referred to caste or discrimination based on work and descent.

\begin{tabular}{|l|l|l|}
\hline Country & Treaty Bodies & $\begin{array}{l}\text { Year of Concluding } \\
\text { Observations }\end{array}$ \\
\hline Bangladesh (7) & CCPR & 2017 \\
\cline { 2 - 3 } & CERD & 2001 \\
\cline { 2 - 3 } & CRC & $2015 ; 2009 ; 2003$ \\
\cline { 2 - 3 } Sri Lanka (4) & CEDAW & $2015 ; 2011$ \\
\hline & CERD & 2016 \\
\cline { 2 - 3 } & CRC & $2010 ; 2018$ \\
\cline { 2 - 3 } & CEDAW & 2017 \\
\cline { 2 - 3 } & CCPR & 1991 \\
\cline { 2 - 3 } & CESCR & 2017 \\
\hline
\end{tabular}

${ }^{26}$ IDSN. 2021. Caste Discrimination and Human Rights- Compilation of UN References. Retrieved from https://idsn.org/wp-content/uploads/2021/01/UNcompilation-Jan-2021.pdf. 


\begin{tabular}{|c|c|c|}
\hline Country & Treaty Bodies & $\begin{array}{l}\text { Year of Concluding } \\
\text { Observations }\end{array}$ \\
\hline \multirow[t]{5}{*}{ Japan (10) } & CERD & $2014 ; 2010 ; 2001$ \\
\hline & CEDAW & 2009,2016 \\
\hline & CRC & $2004 ; 2010$ \\
\hline & CESCR & 2001 \\
\hline & CCPR & $2014 ; 1998$ \\
\hline United Kingdom (3) & CERD & $2016 ; 2011 ; 2003$ \\
\hline \multirow[t]{4}{*}{ Yemen (9) } & CERD & $2011 ; 2006$ \\
\hline & CESCR & $2011 ; 2003$ \\
\hline & CRC & $2014 ; 2005 ; 1999 ; 1996$ \\
\hline & CCPR & 2012 \\
\hline Nigeria (I) & CERD & 2005 \\
\hline \multirow[t]{3}{*}{ Mauritania (3) } & CERD & 2004 \\
\hline & CRC & 2009 \\
\hline & CEDAW & 2014 \\
\hline Madagascar (I) & CERD & 2004 \\
\hline \multirow[t]{2}{*}{ Senegal (3) } & CERD & $2012 ; 2002$ \\
\hline & CRC & 2016 \\
\hline Chad (2) & CERD & $2013 ; 2009$ \\
\hline Mali (I) & CERD & 2002 \\
\hline Ethiopia (2) & CERD & $2009 ; 2003$ \\
\hline Ghana (I) & CERD & 2003 \\
\hline Mauritius (2) & CERD & $2013 ; 1996$ \\
\hline Burkina Faso (2) & CERD & $2013 ; 1997$ \\
\hline Micronesia (I) & CRC & 1998 \\
\hline Suriname (I) & CERD & 2015 \\
\hline $\begin{array}{l}\text { Total number of } \\
\text { concluding remarks on } \\
\text { CDWD in Treaty Bodies }\end{array}$ & $\begin{array}{l}\text { CERD (39); CRC (24); } \\
\text { CESCR (9); CEDAW } \\
\text { (I4); CAT (I); } \\
\text { CCPR (8) }\end{array}$ & $\begin{array}{l}\text { Asia (56); } \\
\text { Africa (19); } \\
\text { Middle East (9); } \\
\text { Europe (3); } \\
\text { The Americas (1) }\end{array}$ \\
\hline
\end{tabular}

(d) The UN Special Rapporteurs: Table 2 in the Annexure lists the twenty UN Special Rapporteurs, UN Working Groups or UN Independent Experts who have made references addressing caste-based discrimination or discrimination on work and descent during the period 2005 to $2017 .{ }^{27}$ To be noted is that IDSN has meticulously documented these data by culling out these references from the vast UN sources.

${ }^{27}$ Ibid. 
Table 2: List of UN Special Procedure Mandate Holders who have made references and recommendations on Caste and/or Discrimination on Work and Descent

\begin{tabular}{|c|c|}
\hline S. No. & UN Special Procedure Mandate Holder \\
\hline I & Special Rapporteur on racism, racial discrimination, xenophobia and related intolerance \\
\hline 2 & $\begin{array}{l}\text { Special Rapporteur on contemporary forms of slavery, including its causes and } \\
\text { consequences }\end{array}$ \\
\hline 3 & Special Rapporteur on minority issues \\
\hline 4 & $\begin{array}{l}\text { Special Rapporteur on adequate housing as a component of the right to an adequate } \\
\text { standard of living, and on the right to non-discrimination in this context }\end{array}$ \\
\hline 5 & Special Rapporteur on the right to food \\
\hline 6 & Special Rapporteur on the right to education \\
\hline 7 & Special Rapporteur on the situation of human rights defenders \\
\hline 8 & $\begin{array}{l}\text { Special Rapporteur on torture and other cruel, inhuman or degrading treatment or } \\
\text { punishment }\end{array}$ \\
\hline 9 & Special Rapporteur on violence against women, its causes and consequences \\
\hline 10 & Special Rapporteur on freedom of religion or belief \\
\hline II & $\begin{array}{l}\text { Special Rapporteur on the issue of human rights obligations related to access to safe } \\
\text { drinking water and sanitation }\end{array}$ \\
\hline 12 & Special Rapporteur on human rights and extreme poverty \\
\hline 13 & $\begin{array}{l}\text { Special Rapporteur on the right of everyone to the enjoyment of the highest attainable } \\
\text { standard of health }\end{array}$ \\
\hline 14 & $\begin{array}{l}\text { Special Rapporteur on the promotion and protection of the freedom of opinion and } \\
\text { expression }\end{array}$ \\
\hline 15 & UN Working Group on discrimination against women in law and practice \\
\hline 16 & Special Rapporteur on extrajudicial, arbitrary or summary executions \\
\hline 17 & Special Rapporteur on the rights to freedom of peaceful assembly and of association \\
\hline 18 & Special Rapporteur on the sale of children, child prostitution and child pornography \\
\hline 19 & UN Working Group of Experts on People of African Descent \\
\hline 20 & Independent Expert on the enjoyment of all human rights by older persons \\
\hline
\end{tabular}

Among the UN Special Procedures Mandate Holders, there have been quite a few who have made consistent efforts to bring to light the DWD or caste discrimination in their reports to the Human Rights Council. In 2009, a group of Special Procedures Mandate Holders have brought to light the issue of caste and other forms of discrimination in a joint memo as their significant contribution during the Durban Review Conference (DRC).

Rita Izsàk-Ndiaye, the UN Special Rapporteur on Minority Issues, in March $2016^{28}$ had consistently raised this issue and brought it to the notice of the HRC stating that DWD and caste discrimination constitute serious human rights violation prevalent

${ }^{28}$ Rita Izsák-Ndiaye. Report of the Special Rapporteur on Minority Issues. UN. Human Rights Council. 2016. Retrieved from https://digitallibrary.un.org/record/831486?ln=en\#record-filescollapse-header. 
in several countries and that this needs to be urgently addressed. What is important to note here is that this brought ire to many states which expressed their displeasure against the mandate holder.

What is to be highlighted here is that the norm entrepreneurship coordinated by the Dalits and those in solidarity has been remarkable in this third phase. It generated a vast amount of data and evidence across all the continents on the prevalence of DWD and its effects on communities. Moreover, the member states' failure to effectively address the human rights violations has been brought out powerfully in this phase. General Recommendation 29, after an intense thematic discussion at the CERD, is an important milestone of this phase. Further, a significant contribution in this phase is the document of the two special rapporteurs, Yozo Yokota and Chin-Sung Chung, namely, 'The Principles and Guidelines to Eliminate Discrimination based on Work and Descent', an essential tool for policy guidance, monitoring and review. Later, as observed earlier, with the transition in the UN structure of the Sub-Commission for Protection and Promotion of Human Rights to the HRC in 2006, the Principles and Guidelines for Elimination of DWD was left in limbo. It was neither rejected nor accepted by the Human Rights Council. Needless to say, that the resolve of the member states to resist any appeal to address DWD began to get stronger in the period of the HRC.

The UN General Assembly resolved to convene in 2009 the DRC. It did not evoke much of a response from the NGOs nor the Member States as its relevance then was much debated owing to the contradictions that had surfaced in WCAR among the various countries on such issues as racial discrimination, caste discrimination, reparation for colonial slavery, etc. Dalit organisations, however, participated in the NGO events prior to and during the DRC in 2009, although with only a handful of delegates including a small cultural team. What needs to be underlined here is that in the DRC Outcome Document, ${ }^{29}$ no significant changes were visible regarding the position of the Member States on the Dalits and their concerns, and thus once again 'work and descent-based discrimination' was left out. However, the Dalit organisations and those in solidarity with them did not give up the process of norm entrepreneurship but continued it perseveringly and persistently after DRC.

(e) Guidance Tool for UN functionaries to address the concerns of Dalits and Descent based Discrimination Communities. Due to repeated advocacy efforts of IDSN and Dalit groups, the OHCHR prepared an inclusive guidance tool on caste-based discrimination in 2017, titled, 'Guidance Tool on Descent-Based Discrimination: Key Challenges and Strategic Approaches to Combat Caste-Based and Analogous Forms of Discrimination'. This tool is to be used by UN agencies and other stakeholders in addressing caste-based discrimination. This is probably the first such instrument for the UN functionaries on identifying the communities discriminated by descent, and what areas and the strategies are to be used to work with them.

This phase has been the most effective in framing policies to address caste-based discrimination leading to the wider phenomenon of discrimination on work and descent.

\footnotetext{
${ }^{29}$ Outcome Document of the Durban Review Conference. Retrieved through https://www. un.org/en/durban review2009/pdf/Durban_Review_outcome_document_En.pdf
} 
The mobilization of Dalit communities and those in solidarity in the entire process of the preparatory conferences and during the Durban World Conference has galvanized other UN bodies like the Committee for Elimination of Racial Discrimination and the Sub-Commission, and later the Human Rights Council and the Special Measures of Mandate Holders had begun to evolve policy measures to address caste discrimination.

To be recognized is that the CERD and other HRC bodies have captured the concerns of the CDWD from its myriad angles-from the civil and political rights, broad spectrum of social-political and cultural rights, economic rights and also individual and collective rights.

More importantly, the CERD and other HRC bodies have also captured the geographical spread of the incidence of DWD in at least twenty-six countries-across Asia-Pacific including the Middle East ( 8 countries) and Africa (Mauritania, Mali, Niger, Senegal, Ghana, Nigeria, Burkina Faso, Mauritius, Somalia, Ethiopia); the Dalit diaspora in UK and USA have also been identified, thereby confirming this issue as a global concern with a UN mandate to address it.

However, the members states continue to resist strongly that (1) caste is not race, (2) countries already have laws to address this issue, and (3) it is an ancient system which will take its due course to disappear.

At this juncture, the Dalit organisations led by NCDHR and the IDSN and all those in solidarity decided to make a shift in their strategy. This then marks the beginning of the fourth phase. The shift has a focus more on the global nature of DWD and to mobilise the communities across the world on this issue. The location of this has also shifted from Geneva with the HRC to New York where the UN General Assembly and ECOSOC functions.

(f) Parliamentary Resolutions and Motions. From 2006 to 2018 and beyond, several Dalit solidarity bodies and leaders have urged their respective parliaments to take cognizance of the CDWD including 'untouchability' and caste-based discrimination across the world and to take necessary steps to address in all the areas as they deal with respective governments and also in their trade and development initiatives. Prominent among them are the three resolutions passed by the European Parliaments in 2006, 2012 and 2013 and the motion passed by the Australian Parliament in 2018.

\section{European Parliament Resolutions}

The first EU Parliament resolution on the Human Rights situation of Dalits in India was in $2006^{30}$ which expressed concern over the lack of substantive EU engagement with the Indian Government, notably within the EU-India Summits, on the vast problem of caste-based discrimination. The resolution urged the EU members of the Joint Action Committee to develop dialogue on the problem of caste-based discrimination in terms of its discussions on democracy and human rights, social and employment policy and development cooperation. EU resolution reiterated its expectation that EU

${ }^{30}$ European Parliament. Human Rights of Dalits in India: European Parliament resolution on the human rights situation of the Dalits in India. 1 February 2001. Retrieved from https://www. europarl.europa.eu/doceo/ document/TA-6-2007-0016_EN.html?redirect 
development programmes in India include specific measures to ensure that minorities such as Dalits and Adivasis and other marginalised communities, tribes and castes, are able to close the wide gap with the rest of the population regarding the attainment of the Millennium Development Goals.

Due to the consistent concerns being raised in the UN and related bodies by Dalit solidarity bodies in the EU countries, EU Parliament passed its second resolution ${ }^{31}$ in December 2013 which called for the EU to promote the draft UN Principles and Guidelines for the Effective Elimination of Discrimination based on Work and Descent as a guiding framework for eliminating caste discrimination, and to promote their endorsement by the UN HRC. EU Calls on the Commission to recognise caste as a distinct form of discrimination rooted in the social and/or religious context, which must be tackled together with other grounds of discrimination, i.e. ethnicity, race, descent, religion, gender and sexuality, in EU efforts to fight all forms of discrimination; calls for the EU, in its policies and programmes, to consider people affected by caste-based discrimination as an identifiable group; The EU Parliament urged the Commission and the European External Action Service (EEAS) to mainstream the fight against caste-based discrimination in EU legislation, policies and programming documents and to adopt operational guidelines for its implementation and called on the EEAS to enhance monitoring and evaluation mechanisms to assess effectively the impact of EU action on the situation of people affected by this form of discrimination.

The third EU Parliament resolution passed ${ }^{32}$ in 2013 built on the previous two resolutions in 2006 and 2012. This resolution based its recommendation on the CERD General Recommendation 29, the draft UN Principles and Guidelines for the Effective Elimination of Discrimination based on Work and Descent, published by the HRC and citing the serious concerns, observations and recommendations of the UNHCHR with regard to caste discrimination. It also took cognizance of the recommendations by UN Treaty Bodies and UN Special Procedures Mandate-Holders on the topic of caste based discrimination (CBD).

This third EU resolution recognised that despite the steps taken by the governments of some caste-affected countries, caste discrimination and untouchability continue to be widespread and persistent, It encouraged the EEAS to strengthen its policy and human rights dialogues and promote joint initiatives to eliminate caste discrimination with the governments of states, such as India, Nepal, Pakistan, Bangladesh and Sri Lanka, where caste-affected communities are subjected to so-called 'untouchability practices', and, more broadly, to combat discrimination based on work and descent, which occurs in various countries, including Yemen, Mauritania, Nigeria, Senegal and Somalia - which has gone unmentioned in agreements with many of these states.

This third resolution also called for the inclusion of caste-based discrimination as a human rights issue in future EU human rights policies, strategies and action plans.

\footnotetext{
${ }^{31}$ European Parliament. Caste Discrimination in India: European Parliament resolution of 13 December 2012 on caste discrimination in India (2012/2909(RSP). 13 December 2012. Retrieved from https://www.europarl.europa. eu/doceo/document/TA-7-2012-0512_EN.html?redirect

${ }^{32}$ European Parliament. Caste based discrimination: European Parliament resolution of 10 October 2013 on caste-based discrimination (2013/2676(RSP). 10 October 2013. Retrieved from https://www.europarl.europa.eu/doceo/ document/TA-7-2013-0420_EN.html?redirect
} 
It urged the EU Commission to provide stronger support for development projects combating caste-based discrimination as a serious human rights violation that exacerbates poverty, and to take this form of discrimination into account in all projects with a focus on education, women, access to justice, political participation or labourers in relevant countries. It specifically urged the Commission to develop and apply castesensitive approaches in times of humanitarian crisis and ensure that humanitarian aid is delivered to all marginalised groups, including people suffering from caste-based discrimination. It also urged the Commission and the EEAS to include, where relevant, a 'caste-based discrimination clause' in all trade and association agreements, including affirmative action for Dalits and similarly affected people in the labourers market and the private sector. As the SDGs were being discussed and being developed at that time in 2013, this resolution called for the EU to promote a caste-sensitive post-2015 development agenda, with the reduction of inequalities based on or aggravated by caste as a crucial and measurable goal, ensuring that caste discrimination is explicitly addressed as a major structural factor underlying poverty, and as a root cause of structural inequalities.

\section{Australian Senate Motion ${ }^{33}$}

Senator Lee Rhiannon of the Australian Senate, in June 2018, placed a motion which was passed. She stated that there are over 260 million people across the globe, including around 210 million Dalits in South Asia who face discrimination based on work and descent, including caste and untouchability, as well as Burakumin communities in Japan and those in Africa, Latin America (Quilombo) and Europe (Romani). She called on the Australian Government to develop and apply sensitive approaches in times of humanitarian crisis and ensure that humanitarian aid is delivered to all marginalised groups, including people suffering from DWD. She also urged the Australian business partners to promote more inclusive recruitment and management practices in countries where caste discrimination is prevalent and to strengthen the policy and human rights dialogues and promote joint initiatives to eliminate DWD together with the governments of states, such as Bangladesh, India, Nepal, Pakistan, and Sri Lanka. She urged Australia's international development program to provide support for projects combating DWD as a serious human rights violation that exacerbates poverty.

(g) Parliamentary Forums. Asia Parliamentarians Forum on Dalit Concerns (APFDC) ${ }^{34}$ is a forum of Parliamentarians from South Asia, which was formed to address the issue of discrimination and exclusion faced by the Dalit and excluded communities. The Forum came to exist at the South Asian Parliamentarians' Conference on 'Dalit Concerns: Enabling Equity and Inclusion'. It aims to engage with governance institutions and actors in South Asian countries, individually and

\footnotetext{
${ }^{33}$ Commonwealth of Australia. Parliamentary Debates - The Senate Motions Discrimination Based on Work And Descent. 27 June 2018. Retrieved from https://parlinfo.aph.gov.au/parlInfo/ genpdf/chamber/hansards/ bccfc0a7-1a8d-4257-b829-fa7e3b0f0fc7/0104/hansard_frag.pdf;fileType $=$ application $\% 2 \mathrm{Fpdf}$

${ }^{34} \mathrm{ADRF}$. Asia Parliamentarians' Forum on Dalit Concern. Retrieved from http:// asiadalitrightsforum.org/assets/publications/doc/65643492Asia\%20Parliamentarians\%20 Forum\%20on\%20Dalit\%20Concerns\%20(1).pdf
} 
collectively, to address Dalit concerns in South Asia. It also enables Parliamentarians from across the region to share knowledge and learning that can strengthen the work being done in their respective countries towards promoting equitable and inclusive growth and development.

\section{International Parliamentary Forum on the DWD Concerns $(\text { IPFoD) })^{35}$}

Parliamentarian representatives from nine countries formed the International Parliamentarians Forum on DWD with Hon. Meena Biswakarma (Parliamentarian from Nepal) as the Convener and Hon. Mohammad Nur Iftin (Somalian Parliamentarian) as Co-convener. This International Parliamentarians Forum focuses on the engagement and interventions of Parliamentarians on DWD issues, nationally and internationally, including before the UN and its various organs. This Forum also has support from some parliamentarians from Europe. The IPFoD members have decided to strengthen this forum in order to demand inclusive development for the peoples discriminated by work and descent at the UN and at the domestic level in their respective countries. This Forum is slowly growing in Africa, Asia and in other regions.

\section{The UN General Assembly and ECOSOC phase}

Dalits and CDWD have shifted their focus to intervene at the UN General Assembly and the Economic and Social Council (ECOSOC) to continue with a view to evolve norm entrepreneurship of developing policies which would effectively address DWD concerns. The previous 15 years were spent on the HRC mechanisms, mostly at the Geneva hub of the UN. Considerable elements of policy for addressing discrimination based on work and descent including caste were developed at the HRC. A stalemate seems to have emerged at the HRC in Geneva. Treaty Bodies and Special Rapporteurs and other mechanisms have noted, pointed out and directed member states that they have not got traction at the domestic front. At this stage there was a re-think on the strategy by the Dalit groups, primarily headed by the ADRF to shift gears and to strategise an effective theory of change for UN to address DWD and also Dalit and other concerns that have already been brought out during a decade and half.

This phase of the involvement at the UN General Assembly can be seen in five areas of work:

i) Engage with the regional mechanisms of UN HLPF to have a broader base and to build pressure from below;

ii) Intervene at the UNGA bodies - the HLPF of SDGs, Financing for Development and the UN Third Committee;

iii) Build a global forum and expand the spectrum of DWD communities from Asia to Africa and Latin America and to link with Roma, Sinti, Gypsy and Traveller Groups in Europe;

\footnotetext{
${ }^{35}$ Trust Africa. A week to speak on discrimination based on work and descent: Leaving no one behind. Retrieved from https://www.trustafrica.org/Fr/les-ressources2/actualites/item/3453-aweek-to-speak-up-on-discrimination-based-on-work-and-descent-leaving-no-one-behind
} 
iv) Engage with the UN Member States to form an informal Working Group on CDWD;

v) Entry in the UN DESA - liaison body - to enter into the MGOS Coordination Mechanism

This strategy necessitated the need to evolve and strengthen a global platform of CDWD from across the regions. The first initiative was the Asia Dalit Solidarity Forum which brought actors together from Dalit organisations in Bangladesh, India, Nepal, Pakistan and Sri Lanka, who were primarily Dalit rights forums or those in solidarity with Dalit rights cause. Buraku Liberation League (BLL) and their international movement International Movement against All forms of Discrimination and Racism (IMADR) functioning in Japan and the Dalit groups in Malaysia initially also were connected but later it was mostly the South Asian Dalit rights groups who were actively engaged in the Asian global network process.

i) Engaging with the regional mechanisms of UN HLPF. ADRF started its campaign for the inclusion of DWD in the regional mechanism in Asia. UN ESCAP, based in Bangkok, is the regional hub for the UN SDG in the Asia Pacific region of UN. The NGOs in this region have formed Asia Pacific Regional Civil Society Engagement Mechanism (APRCEM), a civil society platform, aimed at enabling stronger cross constituency coordination and ensuring that all sub-regions of Asia Pacific are heard in intergovernmental processes at a regional and global level. ADRF researched and brought out an advocacy note demanding a goal with the agenda to end caste, work and discrimination by 2030 through a publication 'Dalits and the Post 2015 Development Agenda'. ${ }^{36}$ ADRF continued with an appeal to address the concerns of Dalits and DWD in the Asian region and participated in the official UN Asia Pacific Forum for Sustainable Development (APFSD). Through this, the regional platform was strengthened and the issues of Dalits, mainly from South Asia, were represented. The gain from this engagement with APFSD is that in 2019 a separate constituency has been allotted for 'Dalits and DWD' for the concerns of DWD in general.

ii) Interventions at the UN HLPF. ADRF together with collaborating partners in Asia, Europe and North Americas gathered at the UN New York headquarters in order to engage with international NGOs and UN experts to appeal for elimination of DWD with the publication '260 Million Dalits Appeal for Inclusion in the Post 2015 Sustainable Development Goals (SDG)'. ${ }^{37}$

In fact, since the start of the UN SDGs in 2015, ADRF has been planning and organising several events by collaborating with several international organisations to highlight the need for inclusion of the concerns of DWD communities in achieving sustainable development goals. The prominent series of events were held, along with Regions Refocus and other International NGOs in New York, when the SDGs were presented and accepted by the General Assembly at UN, New York in 2015.

\footnotetext{
${ }^{36}$ ADRF. Dalits and the Post 2015 Development Agenda: Addressing the hidden apartheid of millions will be key to the success of the SDGs. New Delhi: Asia Dalit Rights Forum. Retrieved from http://asiadalitrightsforum.org/ assets/publications/doc/13645922013.pdf

${ }^{37}$ ADRF. 260 Million Dalits Appeal for Inclusion in the post 2015 Sustainable Development Goals. New Delhi: Asia Dalit Rights Forum. Retrieved from http://asiadalitrightsforum.org/ assets/publications/doc/ 1142297951123.pdf
} 
Around 150 delegates were present from the South Asia region together with the Dalit diaspora from US and Canada. Nine Parliamentarians from Asia also joined this effort to include the issue of DWD rights in the SDGs. In the same year ADRF participated in the Civil Society Forum during the Third International Conference of Financing for Development (FfD) advocating for the financial inclusion of CDWD. ${ }^{38}$ Measures suggested at the FfD were: (1) To address barriers to development due to DWD discrimination; (2) Financial inclusion of the Socially Excluded, especially of gender and caste inclusion; and (3) Targeted Budget Allocations for the intergenerationally excluded DWD communities.

ADRF participated in the Sixth Meeting of the Inter-Agency and Expert Group on the Sustainable Development Goal Indicators on 14 November 2017 at Manama, Bahrain, placing an appeal for a clear data disaggregation to monitor the development indicators for CDWD and other social groups.

In 2016, ADRF organised two side events: (i) 'Leave No One Behind - Ensuring Inclusion of the Most Marginalised and Socially Excluded Communities in SDGs' along with Minority Rights Group International, CIVICUS, Asia Development Alliance, Rural Development Centre, Stakeholder Forum for Sustainable Future and Global Call to Action Against Poverty; (ii) Another side event, 'Inclusion Check: Dalit and other Marginalised Women Challenging Inequalities in SDGs 2030' was also held; several international NGOs and members of the Permanent Missions at the UN participated and expressed an interest to promote the concerns of the DWD communities in the SDGs.

Every year from 2015 onwards till 2019, Dalit organisations headed by ADRF have been organising a series of events, numbering eleven, to bring to light the concerns of DWD communities and placing suggestions for addressing them the HLPF which is the monitoring body of the SDGs at the UN in New York. ADRF has also collaborated with several international organisations such as CIVICUS, Global Call to Action against Poverty (GCAP), Amnesty International, Asian Development Alliance, Save, Regions Refocus, Minority Rights Group International, Development Centre, Stakeholder Forum for Sustainable Future, Dr Ambedkar International Mission in order to mobilise support to the CDWD cause. One notable feature is that the UN Women has actively supported and engaged with the CDWD groups to bring to light their concerns in the UN HLPF.

iii) To build a Global Forum for expanding the spectrum of DWD. The shift from a Dalit-focussed advocacy to CDWD-based advocacy needed a theoretical framework for a common identity of DWD groups across the continents. The implication was the need to recognize and understand the disadvantages, restrictions and barriers faced by CDWD across the continents. A publication explaining the basis for this was brought out in 2018, namely, 'A Framework on Discrimination Based on Work and Descent, Including Caste' ${ }^{39}$

${ }^{38}$ ADRF. Promoting Inclusive Economic growth of Communities Discriminated on Work and Descent (Caste). New Delhi:Asia Dalit Rights Forum. Retrieved from http://asiadalitrightsforum. org/assets/publications/ doc/1102077081ffd3-new.pdf

${ }^{39}$ ADRF. Towards a unifying global identity: A Framework on Discrimination based on Work and Descent, Including Caste. New Delhi: Asia Dalit Rights Forum. 2018. Retrieved from 
In November 2018, ADRF organised exploratory network meetings with groups and individual leaders in Africa-Nairobi, Kenya and Addis Ababa, Ethiopia - on the Discrimination based on Work and Descent. The similarities between the caste-based discrimination found in South Asia and the social systems which caused enslavement of certain communities Somalia, Ethiopia, Kenya and other East African countries were starkly clear and striking.

Following on the visit to East Africa, ADRF had discussions with groups from western Africa facilitated by Trust Africa organization and then reached out to a group of organisations in the Sahel region working with communities forced into the traditional forms of enslavement. Following this, in April 2019 the Dakar Consultation was held on the theme 'Discrimination based on Work and Descent in Africa Exploring UN Mechanisms' and organised by The Inclusivity Project, Trust Africa, Asia Dalit Rights Forum, Amnesty International, Dalit Solidarity in Deutschland, African Regional UNESCO, SAVE international, Regional GCAP and others. At the end of the consultation, the African groups met to decide on the formation of ANDS.

With this ground work standing as backdrop, the International Congress of Communities Discriminated on Work and Descent (ICDWD) was held in New York from 21-23 September 2019 with 121 representatives from 24 countries. The aim was to forge a global forum calling upon the United Nations and States Parties to adopt effective measures toward ending all forms of discrimination and violence based on work and descent, casteism, antigypsyism, traditional and contemporary forms of slavery and other analogous forms of discrimination. Accordingly, deliberating on the need to have a global forum of peoples similarly discriminated on work and descent, ICDWD formed a global network and came out with the New York Declaration to be presented to the United Nations and Member States and other international agencies.

New York Declaration: Global Call To Eradicate Discrimination And Uphold Human Dignity And Equality: ${ }^{40}$ Citing the preamble of the Universal Declaration of Human Rights (UDHR); taking note of several attempts been made under international human rights law to eliminate discrimination and violence based on work and descent, casteism, antigypsyism, traditional and contemporary forms of slavery and other analogous forms of discrimination, while at the same time feeling appalled at the impunity manifested by state and non-state, the ICDWD called on the United Nations and its Member States: (1) to adopt the 'Draft Principles and Guidelines for the Effective Elimination of Discrimination Based on Work and Descent'; (2) to declare a Decade of DWD Communities that will focus on combating discrimination and violence based on work and descent, casteism, antigypsyism, traditional and contemporary forms of slavery and other analogous forms of discrimination; (3) to establish a Special United Nations Fund to support the effective participation of DWD communities in all national, regional and international processes geared towards eliminating discrimination and violence based on work and descent, casteism,

http://www.ncdhr.org.in/wp-content/uploads/2018/12/648455134Global-report-single-pageformat.pdf

${ }^{40}$ New York Declaration. 24 September 2019, Global Call To Eradicate Discrimination And Uphold Human Dignity and Equality. Retrieved from http://asiadalitrightsforum.org/assets/ publications/doc/New_York_Declaration_b9ja6.pdf 
antigypsyism, traditional and contemporary forms of slavery and other analogous forms of discrimination; and (4) to adopt a Declaration on the Rights of the CDWD.

The New York Declaration also called on the member states: (1) to officially recognize the people, culture and the rich heritage of DWD communities; (2) to establish and implement various legal and policy frameworks, administrative and judicial instruments in order to accelerate equality and justice for all; (3) to ensure that there is no direct or indirect discrimination against women in all its forms; (4) to enact and strengthen national laws and policies that promote gender equality and prevent gender-based discrimination and violence; (5) to ensure accountability of all crimes against women and to end the culture of impunity; (6) to promote the rights and entitlements of children and youth of DWD communities in order to develop their potential to grow as full-fledged citizens; (7) to ensure equitable and proportional representation in governance to members of DWD communities, especially the women; (8) to evolve and implement plans, policies and programs in public and private sectors aimed towards sustainable economic empowerment of DWD communities; (9) to end all forms of state-sponsored violence and repression against DWD communities so as to ensure they live a secured life of equality and dignity; and (10) to establish an independent body of members of DWD communities in order to monitor and review the implementation process of Sustainable Development Goals, 2030.

iv) Engage with the Member States and Parliamentarians. The advocacy efforts have been directed towards two other key areas - the Permanent Missions and the Parliamentarians as they both are critical to evolving policy both at the UN as well as at the domestic levels. In this area three Roundtable Meetings were organised with the Permanent Missions together with the Parliamentarians. In September 2019, a roundtable meet was hosted by the Permanent Mission of the Republic of Senegal to United Nations. Ambassador Cheikh Ndiaye not only addressed the twenty-eight delegates from twelve countries from four continents including nine Parliamentarians from six countries but also gave a commitment to take the DWD concerns to the UN SDG process through the HLPF of SDGs which is the monitoring body for the implementation of the SDGs.

Another Roundtable was organized jointly by the GFoD along with the Permanent Mission of Germany and the International Parliamentarians Forum on DWD during the UN General Assembly week in September 2020. This was a virtual meeting due to the Covid pandemic. It had three objectives: (1) To build solidarity and fellowship among the MPs based on DWD rights cause; (2) To evolve a charter of specific and concrete strategies for effective intervention on DWD issue at global/regional level; and (3) To outline concrete measures for building up IPFoD (International Parliamentarians Forum of DWD) which can operate as an effective platform at global/ regional level. Nine MPs from several countries and the CDWD leaders from eleven countries participated and the German Ambassador gave his commitment to represent this issue to the UN Third Committee specifically on the issue of Safe Drinking Water and Sanitation.

Accordingly, a Roundtable on the access to safe drinking water and sanitation rights for all was hosted by the Permanent Mission of Germany along with the Permanent Mission of Spain and was jointly organised by GFoD with several international organisations. The Roundtable discussed how the communities that are discriminated based on work and descent could be better organized and included in the task of 
achieving SDG 6 and how the UN could be engaged to support these efforts. Starting with this roundtable, there is a greater openness and momentum among the Permanent Missions to discuss and act on the concerns of DWD communities.

v) Entry in the UN DESA — liaison body-so as to enter into the MGOS Coordination Mechanism. Another major breakthrough at the UN General Assembly CSO processes is the formal recognition of the CDWD as part of the MGoS-Major Groups and other Stakeholders. MGoS is a forum of CSOs categorized on the thematic or constituency groups that are recognised by the UN DESA. UN DESA upholds the development pillar of the United Nations and is guided by the UN SDGs processes. Since the time of recognition of Global Forum of CDWDs as a formal part of the NGO interventions in $2021 \mathrm{HLPF}$, CDWD leaders and youth have created space to be part of the panel in the official sessions of the HLPF, and have been selected by the MGoS to intervene through formal statements on behalf of the CDWD communities and their concerns. This latest development is a major breakthrough in the norm entrepreneurship emergence and will lead to the point where possible resolutions may be taken in the future UN Assembly sessions.

\section{Working towards a UN Declaration on the Rights of CDWD}

CDWD number over 260 million spread across all over the globe in all the continents. As observed earlier, the most visible among them are the Dalits of South Asia and the Burakumin of Japan but since the year 2000, the presence of various CDWD has been established across all the continents. They do not have the same narrative of their origin but all of them undergo similarly severe human rights discriminations and violations due to (a) notions of purity and pollution, (b) segregated living, (c) forced unclean occupations and (d) the practice of endogamy.

It is evidenced beyond doubt that CDWD across nations have been 'enslaved' within their own regions/countries. This phenomenon has happened much before the transatlantic slave trade to the northern countries took place. This 'enslavement' still continues in varying forms that are termed as 'modern forms of slavery', and in some countries traditional form of slavery still continues. CDWDs face extreme forms of violence in a routine manner when they assert their rights to dignity, liberty, equality and right to life.

Another peculiar feature of the CDWD is that they have been dis-membered in their location of habitation. They are not present in one geographical section of the country or the region. Even though their overall population percentage at the national level is quite large in proportion to that of other communities, they have been dis-membered into minute or small groups and have been kept under the domain of the settlement of the dominant castes/groups at the village or at a primary habitation level for the purpose of residing close to the dominant castes/groups and providing all kinds of menial services to them. This in fact is a manipulative strategy of managing a fairly large group of minority populations under the control of the dominant castes/groups. This has been found to be true not only within a given country but also across the globe. It can very well be said that this has been the reason for this DWD issue to have remained invisible for centuries and being able to survive international scrutiny for over a few decades. 
Except for a handful of nation states who have ensured legislated rights protecting CDWD right to life in their territories, most DWD communities still continue their life of being vulnerable to and being exposed to exclusion and violence. In each of those countries where the DWD practices exist, there have been several attempts by the people to protect themselves by demanding policy frames from their governments to address these forms of discrimination and violence. In this respect, it is to be noted that this process of norm emergence is becoming stronger in South Asia.

Historically, CDWD have attempted to reverse the dominant caste/group's dismemberment strategy that has caused the communities to be split into small groups scattered all over the sub-national spaces. Efforts in the South Asian region brought the CDWD under one identity in the colonial period. Dr. B. R. Ambedkar, an icon of the Dalits in South Asia has given them the term 'depressed classes' which later was known as as Scheduled Castes and then further on as Dalits. Today this term has come to be accepted in most of the South Asian countries.

United Nations took efforts to bring the concerns of these communities right at the time of constituting the Universal Declaration of Human Rights, the prime charter of rights of the United Nations, but the attempts did not succeed. There is documentary evidence to show that W. E. B. Dubois has reached out to Dr. B. R. Ambedkar who brought the concerns of Dalits to the international audience, but for some reason the UN did not bring the specific concerns of Dalits into its legal purview. In contrast, however, the concerns of the racial minorities were brought within the legal framework of the UN Charter.

Recent decades, however, have seen positive trends. For the first time CERD recognized in 1996 that the term 'descent' does cover the concerns of Scheduled Castes and that of caste-based discrimination but this was strongly contested by some of the member states at the UN. The member states led by India's representatives stated that caste and race were different. And it was also argued that the caste system is not an 'apartheid system' where the state condones and that the country has constitutional provisions, legislative and administrative measures to curb the practice of caste-based discrimination. It was also contended that the member states have the ability to address the DWD concerns within the countries and so a UN body like CERD does not have to deal with this type of issue.

The WCAR generated an intense discussion once again raising the concerns of CDWD. Dalit groups along with many international human rights organisations also were instrumental in initiating intense debates with irrefutable evidences placed before the UN bodies. However, it appears that some technicalities prevented WCAR from bringing out a resolution on the CDWDs in its Declaration and Programme of Action.

The norm entrepreneurship of the Dalit groups continued, however, and they along with other solidarity bodies have generated enormous systematic evidence for the benefit of several UN bodies - the Treaty Bodies, Special Rapporteurs, Independent Experts and also the Office of the High Commissioner for Human Rights. On the whole eighty-six recommendations were given by CERD, Child Rights Committee, Committee for Economic, Social and Cultural Rights, Committee for the Elimination of Discrimination and Violence against Women, Committee against Torture and Human Rights Committee, referring to DWD issues from all over Asia, Africa, Middle East and the Americas. Twenty-one Special Mandate Holders have officially addressed caste-based discrimination and used the term 'discrimination based on work 
and descent' as distinct and different from race or ethnicity. The Universal Periodic Review of the Human Rights Council has several times raised the issue of DWD and caste-based discrimination, but the Member States continued to resist reporting on the issues of caste-based discrimination.

The Dalits groups at this stage, therefore, shifted their strategy to (a) intervene in the UN General Assembly and the ECOSOC bodies, keeping the SDGs as the primary focus, and b) build a GFoD by involving Asian Dalit communities, African groups challenging traditional and modern forms of slavery, Roma, Gypsy, Sinti communities from Europe and Quilombola communities from Latin America. The Burakumin communities from Japan have expressed interest but have not managed to participate in the ICCDWD held in September 2019. The GFoD was constituted in the same year of the Congress and it continues to challenges DWD and push for norm entrepreneurial engagement at the UN. States of Senegal, Germany and Spain have openly supported the issue of CDWD and appealed to the UN to bring the issue to discussion in the UN.

Given the experience of the past millennia, the CDWD have exhibited enormous amount of resilience, creativity, and fortitude to endure and survive through myriad, intersecting forms of oppression, discrimination and injustice. They have risen to stand in solidarity to claim their humanity, achieve full recognition of their status equal to all other citizens of nation-states. It is already twenty-five years since the first cognizance of the DWD issues had taken place with the formal endorsement of CERD in 1996.

Today, the DWD communities and organizations demand legitimate acknowledgement by the worldwide community, especially the UN to recognise the right to life and dignity of the communities and to evolve norm emergence leading to norm adherence. They are also attempting to constitute a Working Group to promote and draft the Declaration on the Rights of CDWD.

There are some critical lessons to be learnt from the experience of the groups, which while advocating the cause of the indigenous peoples, have managed to demand and get the UN Declaration on the Rights of Indigenous Peoples (UNDRIP) even by crossing over the barriers from the states at the different stages of norm entrepreneurship. No doubt concerns of 'norm adherence' do exist but then concerns of adherence to policies will always remain a challenge to be encountered and responded to adequately and effectively. It is hoped that renewed strategy of CDWD and the systematic efforts of GFoD will result in the long-awaited Declaration of the Rights of CDWD in the near future.

\section{References}

ADRF. Dalits and the post 2015 development agenda: addressing the hidden apartheid of millions will be key to the success of the SDGs. New Delhi: Asia Dalit Rights Forum. Retrieved from http://asiadalitrightsforum.org/assets/publications/doc/13645922013.pdf

—. 260 million Dalits appeal for inclusion in the post-2015 Sustainable Development Goals. New Delhi: Asia Dalit Rights Forum. Retrieved from http://asiadalitrightsforum.org/ assets/ publications/doc/ 1142297951123.pdf

—. Response to Zero Draft of the Sustainable Development Goals. New Delhi: Asia Dalit Rights Forum. Retrieved from http://asiadalitrightsforum.org/assets/publications/doc/28498 8303Revised_ADRF_Response_Post\%202015\%20SDG\%20(1).pdf 
—. Annihilate caste and structural inequalities in implementing the 2030 agenda - September 2015. New Delhi: Asia Dalit Rights Forum. Retrieved from http://asiadalitrights forum.org/ assets/publications/doc/1736746861NCDHR\%20-\%20SDG\%20\%20Nov\%2015. pdf

- Promoting inclusive economic growth of Communities Discriminated on Work and Descent (Caste). New Delhi: Asia Dalit Rights Forum. Retrieved from http://asiadalitrights forum. org/assets/publications/ doc/1102077081ffd3-new.pdf

- Towards a unifying global identity: a framework on discrimination based on work and descent, including caste. New Delhi: Asia Dalit Rights Forum. Retrieved from http://www. ncdhr.org.in/wp-content/uploads/2018/12/648455134Global-report-single-page-format.pdf

- Asia Parliamentarians' forum on Dalit concern. Retrieved from http://asiadalitrightsforum. org/assets/publications/doc/65643492Asia\% 20Parliamentarians\% $\quad$ 20Forum\%20on $\% 20$ Dalit\%20Concerns\%20(1).pdf

Araújo, Eduardo and Maria da Silva, Givânia. (2019). Racism and violence against Quilombalos in Brasil. Confluencias, 21(2), pp.196-208.

Bhaduri, Amita. (2013). Impact of climate change on life \& livelihood of Dalits: an exploratory study from disaster risk reduction lens. New Delhi: NCDHR and SPWD.

Committee on the Elimination of Racial Discrimination. (2003). General Recommendation 29, Discrimination Based on Descent (Sixty-first session, 2002). U.N. Doc. A/57/18 at 111 (2002), reprinted in Compilation of General Comments and General Recommendations Adopted by Human Rights Treaty Bodies, U.N. Doc. HRI $\backslash$ GEN $\backslash 1 \backslash$ Rev.6 at 223 (2003). Retrieved from http://hrlibrary.umn.edu/cerd/genrec29.html.

Commonwealth of Australia. Parliamentary Debates - The Senate Motions Discrimination Based on Work And Descent. 27 June 2018. Retrieved from https://parlinfo.aph.gov.au /parlInfo/ genpdf/chamber/hansards/bccfc0a7-1a8d-4257-b829-fa7e3b0f0fc7/0104/hansard__frag. pdf;fileType=application $\% 2 \mathrm{Fpdf}$

European Parliament. 'Caste Discrimination in India: European Parliament resolution of 13 December 2012 on caste discrimination in India' (2012/2909(RSP). 13 December 2012. Retrieved from https://www.europarl.europa.eu/doceo/document/TA-7-2012-0512_ EN.html? redirect

-. Human rights of Dalits in India: European Parliament resolution on the human rights situation of the Dalits in India. 1 February 2001. Retrieved from https://www.europarl. europa.eu/doceo/document/TA-6-2007-0016_EN.html?redirect

- Caste-based discrimination: European Parliament resolution of 10 October 2013 on castebased discrimination (2013/2676(RSP). 10 October 2013. Retrieved from https://www. europarl.europa.eu/doceo/ document/TA-7-2013-0420_EN.html?redirect

Divakar, Paul. N. and Ajai, M. (2004). UN bodies and the Dalits. In Sukhdeo Thorat and Umakant. (Eds.) Caste, race, and discrimination: discourses in international context. New Delhi: Rawat Publications.

Finnemore, Martha and Sikkink, Kathryn (1998). International norm dynamics and political change. International Organization, 52(4), pp. 887-917.

Florini, Ann. (1996). The evolution of international norms. International Studies Quarterly, 40(3), pp. 363-383.

Global Slavery Index. (2018). Retrieved from https://www.globalslaveryindex.org/

Human Rights Council. (2009). Eleventh Session, Agenda item 5. Human Rights Bodies and Mechanisms. Final report of Mr. Yozo Yokota and Ms. Chin-Sung Chung, Special Rapporteurs on the topic of discrimination based on work and descent. 1A/HRC/11/CRP.3, 18 May 2009. Retrieved from https://www.ohchr.org/Documents/HRBodies/HRCouncil/ RegularSession/ Session11/A-HRC-11-CRP3.pdf 
IDSN. (2021). Caste discrimination and human rights: compilation of UN references. Retrieved from https://idsn.org/wp-content/uploads/2021/01/UNcompilation-Jan-2021.pdf

Izsák-Ndiaye, Rita. (2016). Report of the Special Rapporteur on Minority Issues. UN. Human Rights Council. Retrieved from https://digitallibrary.un.org/record/831486?ln=en\#recordfiles-collapse-header

Lennox, Corrine. (2020). Transnational social mobilisation and minority rights: identity, advocacy and norms. London: Routledge.

New York Declaration, 24 September 2019. Global Call to Eradicate Discrimination and Uphold Human Dignity and Equality. Retrieved from http://asiadalitrightsforum.org/assets/ publications/doc/New_York_Declaration_b9ja6.pdf

Outcome Document of the Durban Review Conference - Retrieved from https://www.un.org/ en/durbanreview2009/pdf/Durban_Review_outcome_document_En.pdf

Ramaswamy, K. (2004). Statement by National Human Rights Commission, India at WCAR. In Sukhadeo Thorat and Umakant. (Eds.) Caste, race and discrimination. New Delhi: Rawat Publications.

Sukhdeo Thorat and Umakant. (Eds.) (2004). Caste, race, and discrimination: discourses in international context. New Delhi: Rawat Publications.

Trust Africa. A week to speak on discrimination based on work and descent: Leaving no one behind. Retrieved from https://www.trustafrica.org/Fr/les-ressources2/actualites/item/3453a-week-to-speak-up-on-discrimination-based-on-work-and-descent-leaving-no-one-behind

United Nations General Assembly. (2016). Human Rights Council. Thirty-first session. Agenda item 3. Report of the Special Rapporteur on minority issues. A/HRC/31/56, 28 January 2016. Retrieved from https://www.ohchr.org/EN/HRBodies/HRC/RegularSessions/ Session31/Documents/A_HRC_31_56_en.doc

- (2017). Human Rights Council. Thirty-fourth session. Agenda item 3. Report of the Special Rapporteur on minority issues o her mission to Iraq. A/HRC/34/5, 9 January 2017. Retrieved from https://documents-dds-ny.un.org/doc/UNDOC/ GEN/G17/002/44/PDF/ G1700244.pdf?OpenElement

- (2013). Human Rights Council. Twenty-third session. Agenda item 9. Report of the Special Rapporteur on contemporary forms of racism, racial discrimination, xenophobia and related intolerance, Mutuma Ruteere. A/HRC/23/56, 2 April 2013. Retrieved from http://idsn.org/ wp-content/uploads/user_folder/pdf/New_files/UN/SP/HRC23_report_SR_Racism.pdf

UN Committee on the Elimination of Racial Discrimination (CERD). (2014). 'UN Committee on the Elimination of Racial Discrimination: Concluding Observations. Mauritania'. 10 December 2004, CERD/C/65/CO/5. Retrieved from https:/www.refworld.org/docid/.html

- (2018). 'Concluding observations on the combined 17th to $23 \mathrm{rd}$ periodic reports of Nepal: Committee on the Elimination of Racial Discrimination'. 29 May 2018. CERD/C/NPL/ CO/17-23. Retrieved from https://digital library.un.org/record/1627709? ln=en

- (2021). Adopted by the Committee at the $104^{\text {th }}$ session (9 - 25 August 2021) List of issues prior to submission of the twentieth and twenty first periodic reports of India

United Nations International Covenant on Civil and Political Rights (2014). Human Rights Committee. Concluding observations on the second periodic report of Nepal. 15 April 2014. $\mathrm{CCPR} / \mathrm{C} / \mathrm{NPL} / \mathrm{CO} / 2$. Retrieved from https://tbinternet.ohchr.org/_layouts/15/treatybody external/Download.aspx?symbolno $=\mathrm{CCPR} / \mathrm{C} / \mathrm{NPL} / \mathrm{CO} / 2 \& \mathrm{Lang}=\mathrm{En}$ 
United Nations International Convention on the Elimination of all Forms of Racial Discrimination. (2007). Committee on the Elimination of Racial Discrimination. Seventieth session. Consideration of Reports Submitted by States Parties Under Article 9 of the Convention: Concluding Observations of the Committee on the Elimination of Racial Discrimination-India. 5 May 2007, CERD/C/IND/CO/19. Retrieved from https://tbinternet. ohchr.org/_layouts/15/treatybodyexternal/Download.aspx?symbolno=CERD/C/IND/ $\mathrm{CO} / 19$ \&Lang=En

United Nations General Assembly (2011). Human Rights Council. Seventeenth session. Agenda item 9. Report of the Special Rapporteur on contemporary forms of racism, racial discrimination, xenophobia and related intolerance, Githu Muigai. 25 March 2011, A/ HRC/17/40/Add.2. Retrieved from https://digitallibrary.un.org/record/ 700115? ln=en

United Nations. (2017). Guidance Tool on Descent-Based Discrimination: Key Challenges and Strategic Approaches to Combat Caste-Based and Analogous Forms of Discrimination - United Nations Network on Racial Discrimination and Protection of Minorities. Retrieved from https://www.ohchr.org/Documents/Issues/ Minorities/GuidanceToolDiscrimination.pdf

UN Committee on the Elimination of Racial Discrimination (CERD). (1996). Concluding Observations, India, 17 September 1996, CERD/C/304/Add.13. Retrieved from https:// www.refworld.org/docid/3ae6aeeb10.html

UN Human Rights Committee (HRC). (1997). Concluding Observations of the Human Rights Committee, Slovakia. 4 August 1997, CCPR/C/79/Add.79. Retrieved from https://www. refworld.org /docid/3ae6b032c.html

United Nations Human Rights. Opinion Piece: Tearing down the wall of caste. UN High Commissioner for Human rights, OHCHR, Geneva. Retrieved from https://newsarchive. ohchr.org/EN/News Events/Pages/DisplayNews.aspx?News ID=9540\&LangID=E

Waughray, Annapurna and Keane, David (2017). CERD and Caste-based Disrimination. In Fifty years of international convention on elimination of all forms of racial discrimination: a living instrument. David Keane and Annapurna Waughray, Manchester: University Press Scholarship Online, pp 121-149.

W.E.B. Du Bois Papers. Series 1. Correspondence Letter from B. R. Ambedkar to W.E.B. Du Bois. Retrieved from https://credo.library.umass.edu/view/full/mums312-b109-i132 